Nig. J. Biotech. Vol. 34 (2017) 12-18

ISSN: 01891731

Available online at http://www.ajol.info/inde

x.php/njb/indexand www.biotechsocietynigeria.org

DOI:https://dx.doi.org/10.4314/njb.v34i1.2

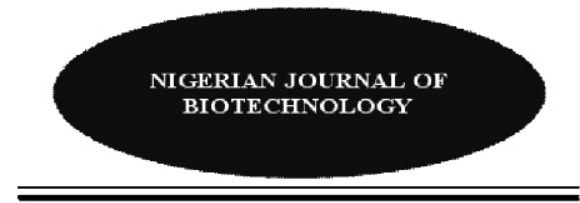

\title{
Bioremediation of soil contaminated with crude oil using fresh and decomposed animal manure
}

\author{
Soretire $^{1 *}$, A. A., Oshiobugie ${ }^{1}$, A. A., Thanni ${ }^{1}$, B. M., \\ Balogun ${ }^{2}$, S. A. and Ewetola ${ }^{1}$, J. M. \\ ${ }^{1}$ Department of Soil Science and Land Management, Federal University of Agriculture, P.M.B. 2240, Abeokuta, Nigeria. \\ ${ }^{2}$ Department of Microbiology, Federal University of Agriculture, P.M.B. 2240, \\ Abeokuta, Nigeria.
}

Copyright resides with the authors in terms of the Creative Commons License. 4.0.

See http://creativecommons.org/licenses/by/4.0/

Condition of use: The user may copy, distribute, transmit and adapt the work, but must recognize the authors and the Nigerian Journal of Biotechnology.

\section{Abstract}

Vast majority of rural dwellers stands to bear the brunt of oil spillage and soil pollution, hence the need to develop remediation options using materials that are cheap and readily available. A laboratory incubation study was conducted to evaluate the bioremediation potentials of different types of animal manure on soil contaminated with crude oil (Forcados). Treatments consisting of $20 \mathrm{t} \mathrm{ha}^{-1}$ each of poultry dropping (PD), swine manure(SM) and beef cattle manure (BCM) both in fresh (f) and partially decomposed $(p)$ forms were applied to soils contaminated with $(5 \% \mathrm{w} / \mathrm{w})$ the crude oil. Their effects were evaluated on total hydrocarbon content (THC), microbial respiration (MR) based on amount of $\mathrm{CO}_{2}$ evolved and $\mathrm{pH}$ in situ during a period of 8 weeks of remediation. There was an improvement in the degree of remediation offered by the various bio-stimulants over time. At 4 weeks after amendment (WAA) the level of degradation of THC was in the order: BCMf $>$ control $>$ SMf $=$ PDf $>$ PDp $>$ SMp $>$ BCMp with 17.2, 16.4, 9.6, 9.6, 9.2 and 5.6>4\% of THC degraded respectively. At 8 WAA, $\%$ degradation was in the order: BCMf $>$ PDp $=$ PDf $>$ SMf $>$ SMp $>$ BCMp $>$ control with 66, $65.2,65.2,64.4,63.6,62.8$ and $61.6 \%$ degradation, respectively. Control was the least while BCMf was the most efficient. Microbial respiration consistently reduced with time in un-remediated soils but BCMf enhanced it over time. This further validates BCMf to be the most efficient in terms of soil remediation. It is, therefore, concluded that fresh beef cattle manure applied at $20 \mathrm{t} \mathrm{ha}^{-1}$ could be very efficient in remediating crude oil polluted soil.

Key words: Total hydrocarbon content, microbial respiration, remediation, biostimulant.

*Corresponding author: (Tel. +2348033579370, email:soradeb@yahoo.com)

\section{Introduction}

The advent of crude oil in Nigeria since commercial exploration of petroleum started in 1958 has made petroleum to be the mainstay of Nigeria's economy. It has brought about lots of job opportunities and advancement in the economy of the country notwithstanding the attendant negative consequences of its exploration. An estimated 9 million - 13 million (1.5 million tons) of oil has been spilled in to the Niger Delta ecosystem over the past 50 years; 50 times the estimated volume spilled in Exxon
Valdez oil spill in Alaska 1989 (FME et. al., 2006)

Leaks and accidental spills occur regularly during the exploration, production, refining, transport and storage of petroleum and petroleum products (Millioli et. al., 2009). The release of hydrocarbons in the environment whether accidentally or due to human activities is a main cause of water, air and soil pollution which tends to impair the conditions of soil. Stanley et. al. (2017) reported that the baseline study of crude oil contaminated soil revealed 
that the amount of limiting nutrients such as nitrogen, phosphorus and potassium present in the polluted soil were very low. Aside affecting soil conditions, the spread of oil have also affected a large area which has necessitated the destruction of fishing grounds and reduction of fish population and also loss of forest and agricultural lands (Ukoli, 2005). Also, oil spills on ocean and land is a lingering menace to most communities close to these regions as it constitutes enormous losses to farmers, fishermen and hunters.

Although many research have been done and a lot of studies over the years on bioremediation all over the world (Farag and Soliman, 2011; Nievas et. al., 2008; Jain and Bajpai, 2012; Sathishkumar et. al., 2008; Zhang et. al., 2010) in a bid to tackle the problem of oil pollution, these reports have been limited to a more scientific approach which the local farmer do not readily have access to or may not be able to understand the technicalities involved. Hence, it becomes imperative to develop cheaper and environmentally friendly options for enhancing petroleum hydrocarbon degradation in polluted soils. One of such options is the use of animal manure as bio stimulating agents. Animal manures have been proven to be good resources for the microbial degradation of contaminated soils (Akinde and Obire, 2008); as it contributes diverse species of microorganisms that are proficient in degrading target pollutant as a result of the enzymes they produce (Adebusoye et. al., 2007). Therefore, this research will help provide information on the use of different animal manure in various forms as biostimulants in contaminated soil. The study was conducted to determine the effect of different forms of manure on soil microbial respiration and biodegradation of crude oil in contaminated soil.

\section{Materials and methods}

\section{Study Location}

The experiment was carried out at the Federal University of Agriculture Abeokuta (FUNAAB), Ogun State, Nigeria, between July and September 2014. The study site lies between latitude $7^{\circ} 12^{\prime}$ to $7^{\circ} 20^{\prime} \mathrm{N}$ and longitude $3^{\circ} 20^{\prime}$ to $3^{\circ} 28^{\prime} \mathrm{E}$.

\section{Soil Sample Collection}

Surface soil sample from $0-15 \mathrm{~cm}$ was collected from FADAMA area in FUNAAB. The soil samples were bulked, air dried, gently crushed and passed through a $2 \mathrm{~mm}$ mesh sieve so as to remove debris and stones. A portion of the soil was used for determination of some physical and chemical properties by standard methods as described below.

\section{Soil Analysis}

The $\mathrm{pH}$ of the experimental soil was determined in 1:1 (soil: water) suspension using a $\mathrm{pH}$ meter. Total nitrogen was determined using Kjeldhal method. Available phosphorus was determined by the Bray- 1 extraction method. Exchangeable bases were extracted with Ammonium acetate at $\mathrm{pH}$ 7. Sodium and potassium were determined using flame photometer while calcium and magnesium were determined using Atomic Absorption Spectrophotometer (AAS). Organic carbon $(\mathrm{OC})$ of the soil was determined using the chromic acid digestion method of Walkley and Black (1934). Total hydrocarbon was determined using Toluene Extraction Method (Adesodun \& Mbagwu, 2008).

\section{Experimental Design}

The experiment was an incubation study and it consisted of 7 treatments arranged in a completely randomized design (CRD). Each treatment was replicated 3 times. The treatment combination is as illustrated below:

Table 1: Treatment combination

\begin{tabular}{|c|c|c|c|c|c|c|}
\hline $\mathrm{Pdd}_{1}$ & $\mathrm{OPd}_{2}$ & (Bm 1 & (Bm 2 & $\mathrm{CS}_{1}$ & $\mathrm{CSN}_{2}$ & $C_{T}$ \\
\hline $\mathrm{Pd}_{1}$ & $\mathrm{OPd}_{2}$ & Brm 1 & Bm 2 & $\mathrm{CS}_{\mathrm{N}_{1}}$ & $\mathrm{CSN}_{2}$ & CTC \\
\hline $\mathrm{Pd}_{1}$ & $\mathrm{OPd}_{2}$ & Brm 1 & (Bm 2 & $\mathrm{CS}_{\mathrm{N}_{1}}$ & $\mathrm{CSS}_{2}$ & CTC \\
\hline
\end{tabular}




$\begin{array}{ll}\text { KEY } & \\ \mathrm{C} & \text { Soil with } 5 \% \text { crude oil contamination } \\ \mathrm{Pd}_{1} & 20 \mathrm{t} \mathrm{ha}^{-1} \text { of partially decomposed poultry manure } \\ \mathrm{Pd}_{2} & 20 \mathrm{t} \mathrm{ha}^{-1} \text { of fresh poultry manure } \\ \mathrm{Bcm}_{1} & 20 \mathrm{t} \mathrm{ha}^{-1} \text { of partially decomposed beef cattle manure } \\ \mathrm{Bcm}_{2} & 20 \mathrm{t} \mathrm{ha}^{-1} \text { of fresh beef cattle manure } \\ \mathrm{Sw}_{1} & 20 \mathrm{t} \mathrm{ha}^{-1} \text { of partially decomposed swine waste } \\ \mathrm{Sw}_{2} & 20 \mathrm{t} \mathrm{ha}^{-1} \text { of liquid swine waste } \\ \mathrm{Tc} & \text { control: without manure }\end{array}$

\section{Experimental procedure}

Triplicate samples of $60 \mathrm{~g}$ of soil were transferred into containers and moistened to $60 \%$ of soil pore space as this is considered the optimum water filled pore space (WFPS) for nitrification (Mosier et. al., 1996). Afterwards, soils were polluted with $5 \%$ crude oil (Forcados), the partially decomposed manures were ground and the clods were broken while the fresh manure needed no preparation. The soil in each container was mixed thoroughly with $20 \mathrm{t} \mathrm{ha}^{-1}$ of the various forms of manures based on the treatment combination. The control treatment (CTc) was prepared with soil contaminated with $5 \%$ crude oil without the addition of manure. The treated soil were thereafter transferred into the bottle and incubated at $25^{\circ} \mathrm{C}$ for eight weeks. The following parameter was determined at 2 weeks interval, microbial respiration, $\mathrm{pH}$ and Total hydrocarbon content (THC) using procedures described below. Percentage of biodegradation (\% D) and bio- stimulant efficiency (BE) were also determined using standardformula.

\section{Microbial Respiration}

Ten (10) millilitres of $0.1 \mathrm{~N} \mathrm{NaOH}$ was poured into smaller bottles and carefully suspended into the jar housing the sample bottles using thread. This was covered air tight and incubated under laboratory condition for eight (8) weeks. The $\mathrm{CO}_{2}$ evolved (an index of microbial respiration measured in milligram calorie per kilogramme of soil $\left(\mathrm{MgCkg}^{-1}\right) \times 10$ was absorbed in $10 \mathrm{ml}$ of $\mathrm{NaOH}$ and titrated against $0.1 \mathrm{~N} \mathrm{HCl}$ and $20 \%$ $\mathrm{BaCl}_{2}$ (200 g in $1 \mathrm{~L}$ of water) and 5 drops of phenolphthalein indicator. The $\mathrm{CO}_{2}$ evolved was calculated using the formula below (Equation1):

$\mathrm{MgC}=(\mathrm{B}-\mathrm{V}) \mathrm{NE} \ldots .($ Equation 1$)$

Where $\mathrm{B}=$ Blank titre $(\mathrm{ml})$

$$
\begin{aligned}
& \mathrm{V}=\text { Sample titre }(\mathrm{ml}) \\
& \mathrm{N}=\text { Normality of } \mathrm{HCl} \\
& \mathrm{E}=\text { equivalent weight } \\
& \text { (In terms of } \mathrm{C}, \mathrm{E}=6 ; \mathrm{CO}_{2}, \mathrm{E}=22 \text { ). }
\end{aligned}
$$

\section{Soil $p H$ Determination}

The $\mathrm{pH}$ of the soil was determined in $1: 1$ soil: water suspension with the aid of $\mathrm{pH}$ meter (McLean, 1982). Ten (10) grams of soil sample was weighed in a bottle; $10 \mathrm{ml}$ of distilled water was added into the soil sample, shaken for 30 minutes and allowed to settle. The pH meter was standardized using buffer 7 and 9. Settled solution was poured into a beaker (leaving the solids). Readings were taken using the $\mathrm{pH}$ meter.

\section{Total Hydrocarbon Content}

The total hydrocarbon content of each sample was determined gravimetrically by toluene extraction (cold extraction) method to provide an estimate of the organic and available form of total hydrocarbon as described by Adesodun and Mbagwu (2008). In this procedure, $10 \mathrm{~g}$ of presieved and well air dried soil was weighed into a container and $20 \mathrm{ml}$ of toluene was added. The soil sample was shaken for thirty 30 minutes and the liquid phase of the extract was filtered using a filter paper. The liquid phase of the extract was measured, using a spectrophotometer at 420 $\mathrm{nm}$. The total hydrocarbon in the soil (absorbed) was estimated with reference to standard curve derived from fresh oil diluted with toluene. The $\%$ Degradation of the Hydrocarbon (Equation 2) was calculated using the equation as described by Ofuegbu et.al. (2015). The efficiency of stimulation was also derived as it helps gives insight to the treatability options offered by the various bio-stimulants approach (Equation3). 


$$
\% \mathrm{D}=\frac{T H C O-T H C i}{T H C o} \times 100 \ldots \ldots . . .(\text { Equation 2) }
$$

Where $T H C O=$ Initial Total Hydrocarbon

THCi - Residual Total Hydrocaron

$$
\text { BE - }[T H C(t)-T H C(u) \times 100 \ldots \text { (Equation) }
$$

Where $T H C(t)=\%$ removal of crude oil in the bio-stimulated soil

THC(u) \% removal of crude oil in the non-bio stimulated soil

\section{Statistical Analysis}

Data Collected were subjected to Analysis of Variance (ANOVA) and the treatment means were separated using Duncan's Multiple Range Test (DMRT). The Statistical Analysis System (SAS, 2000) for windows version 2.2 was used.

\section{Results}

The soil used for the trial was loamy sand, slightly alkaline in reaction ( $\mathrm{pH}$ 7.2) with slightly high total nitrogen content and relatively low organic carbon (Table 2).

Table 2: Some physical and chemical properties of the experimental soil

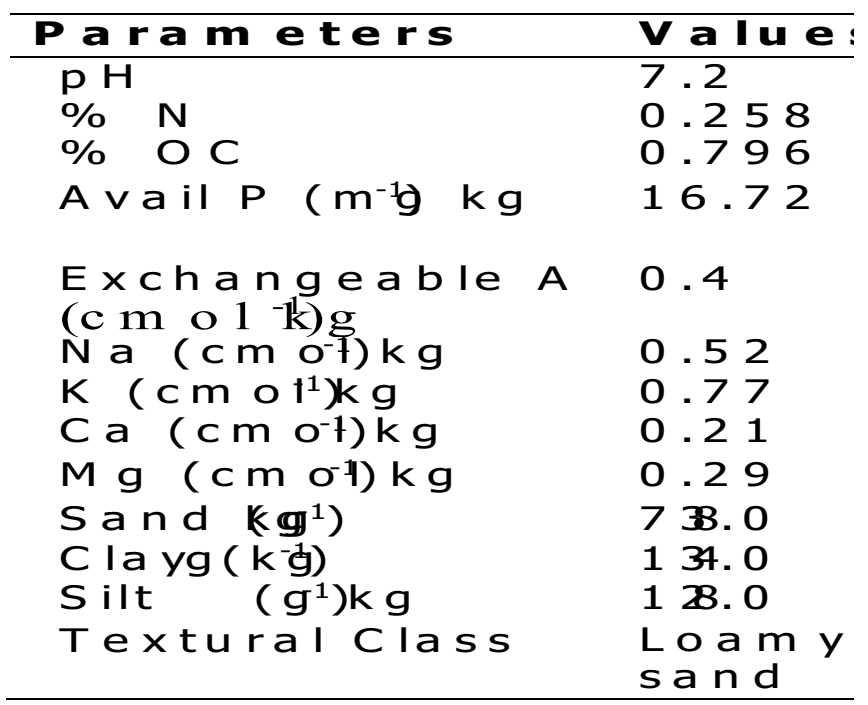

The removal effect of total hydrocarbon content (THC) was used as an indicator parameter for remediation at $5 \%$ crude oil contamination. The THC of contaminated soil was observed to reduce with time for the various applied nutrients (bio-stimulants) (Table 3).
Table 3: Effect of bio-stimulants on the total

\begin{tabular}{|c|c|c|c|c|c|c|c|}
\hline \multirow[t]{2}{*}{ Treatment } & \multirow[b]{2}{*}{$\begin{array}{l}\text { Intial } \\
\text { THC } \\
\left(\mathrm{mg} \mathrm{kg}^{-1}\right)\end{array}$} & \multicolumn{2}{|l|}{ 4WAA } & \multicolumn{2}{|l|}{6 WAA } & \multicolumn{2}{|c|}{ 8WAA } \\
\hline & & $\begin{array}{l}\text { THC } \\
\left(\mathrm{mg} \mathrm{kg}^{+2}\right)\end{array}$ & $\%$ & $\begin{array}{l}\text { THC } \\
\text { (mg kg } \\
\text { 1) }\end{array}$ & $\begin{array}{l}\% \\
0\end{array}$ & $\begin{array}{l}\text { THC } \\
\text { (mg kg } \\
\text { 1) }\end{array}$ & $\% D$ \\
\hline Poultry droppings $(P)$ & 25000 & $22700 a b$ & 9.2 & 195000 & 22 & 8700 & 65.2 \\
\hline Poulty droppings (F) & 25000 & $22600 \mathrm{ab}$ & 9.6 & 195000 & 22 & 8000 & 65.2 \\
\hline Swine marure( $P$ ' & 25000 & $29600 a b$ & 5.6 & $19700 a$ & 21.2 & 9100 & 63.6 \\
\hline Swine manure (F) & 25000 & $22500 a b$ & 9.6 & 169006 & 32.4 & 8900 & 64.4 \\
\hline Beef cattle manure ( $P$ ) & 25000 & 240000 & 4 & 193000 & 228 & 9900 & 62.8 \\
\hline Beef catte manure ( $F$ ) & 25000 & 207006 & 17.2 & 193000 & 228 & 8500 & 66 \\
\hline Conted & $\begin{array}{l}25000 \\
\text { NS }\end{array}$ & 209006 & 16.4 & 20400 & 18.4 & $\begin{array}{l}9600 \\
\text { NS }\end{array}$ & 61.6 \\
\hline
\end{tabular}
hydrocarbon content of crude oil polluted soil

Neans wht simlar letter are not significantly different according to Duncan's mutiple range test (DNRT) $(0<0.05), \mathrm{NS}=$ Not significant at $5 \%$ probablity level. THC. total hydrocarbon content, \% D- percentage degradation, P. partialy decomposed; $F$ - fresh

This indicates that there was an improvement in the degree of remediation offered by the various bio- stimulants. Results obtained generally for Total Hydrocarbon content was significantly different $(P<0.05)$ (especially at 4 and 6 WAA) except at 8 WAA when compared with the initial THC of the control. At 4 WAA, soils remediated with fresh beef cattle manure (BCMf) and the control significantly reduced the hydrocarbon content when compared with soils remediated with partially decomposed beef cattle manure (BCMp). All other amendments had similar effect regardless of the form in which they were applied. The \% of degradation (Fig. 1) further showed that soils remediated with BCMf had higher remediating potential in terms of the amount of THC that was degraded when compared with other bio- stimulants.

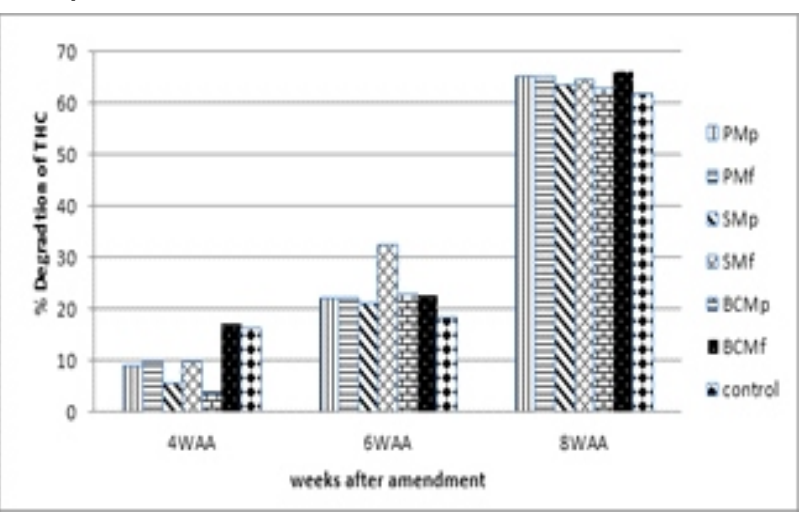

Fig.1: Percentage degradation of various animal manures at 4, 6 and 8 weeks after amendment.

However, the percentage of degradation further shows that although the other manures didn't significantly reduce the THC but they all varied in their remediating potential. The level of degradation was in the order: BCMf $>$ control 
$>$ SMf $=$ PDf $>$ PDp $>$ SMp $>$ BCMp with 17.2, $16.4,9.6,9.6,9.2,5.6$ and $4 \%$ of THC degraded respectively at 4 WAA. At $6 \mathrm{WAA}$, swine manure significantly reduced the THC of contaminated soil. The \% degradation also shows that swine manure fresh had the highest \% degradation while the control had the least. Percent degradation was in the following order: SMf $>$ $\mathrm{BCMf}=\mathrm{BCMp}>\mathrm{PDp}=\mathrm{PDf}>\mathrm{SMp}>$ control with $32.4,22.8,22.8,22,22,21.2$ and $18.4 \%$ degradation respectively. At $8 \mathrm{WAA}$, similar trend was observed in \% degradation of THC. Control was the least effective, while BCMf was the most effective. The bio-stimulating efficiency (BE) shows that all bio-stimulant varied in their $\mathrm{BE}$ at the end of 8 WAA in the order: BCMf $>$ PDp $=$ PDf $>$ SMf > SMp > BCMp with 6.7, 5.5, 5.5, 4.3,3.1 and $1.9 \%$ respectively (Table 4 ).

Table 4: Biodegradation efficiency of various animal manures at 8WAA

\begin{tabular}{|c|c|}
\hline Treatments & Biodegradation efficiency (BE) \\
\hline Poulty droppings $(P)$ & 5.52 \\
\hline Poulty droppings (F) & 5.52 \\
\hline Swine manure $(P)$ & 3.14 \\
\hline Swine manure (F) & 4.34 \\
\hline Beef cattle manure (P) & 1.91 \\
\hline Beof cattle manure $(F)$ & 6.67 \\
\hline
\end{tabular}

Soil amended with Beef cattle manure fresh had the least THC at the end of the experiment as reflected in the bio-stimulating efficiency of BCMf. It was also observed that the least effective bio-stimulant at the end of the study (BCMp) still had relatively lesser THC and $1.9 \%$ bio-stimulating efficiency when compared with the control. All bio-stimulant added to the soil significantly increased the initial soil pH (Table5).

Table 5: Effect of bio-stimulants on $\mathrm{pH}$ of crude oil polluted soil.

\begin{tabular}{|c|c|c|c|c|}
\hline Treatments & 2WAA & $\begin{array}{l}\text { pH values } \\
\text { AWAA }\end{array}$ & 6WA & SWAA \\
\hline Poulty droppings(P) & $7.63^{\circ}$ & $7.23^{\bar{x}}$ & $7.23^{\mathrm{m}}$ & 7.20 \\
\hline Poulty droppings (F) & 7.5700 & $7.53^{\circ}$ & 7.47 & 7.17 \\
\hline Swine manure(?) & $7.67^{\circ}$ & $7.4^{\circ}$ & $7.13=$ & 7.16 \\
\hline Swine manure $(F)$ & 7.5 & $7.37^{\mathrm{b}}$ & $2.4^{k}$ & 7.16 \\
\hline Beef catte manure (P) & $7.5 \%$ & $7.3 x$ & $7.27 x$ & 7.23 \\
\hline Beef catte manure ( $F$ ) & 7.43 & 7.04 & 7.004 & 7.13 \\
\hline Control & 704 & $7.1 \mathrm{ft}$ & $7.27 x$ & 7.23 \\
\hline
\end{tabular}

Means wh similar letter are not significanty different according to Duncan's multople range tes:[DMRT) $(0<0.05)$. P. partaly decomposed; $F$ - fresh changed to slightly alkaline except in control soils in which the $\mathrm{pH}$ was reduced to neutral at 2WAA. The trend changed at 4WAA, as bio-stimulated soil had a decline in $\mathrm{pH}$ values. The $\mathrm{pH}$ of BCMf amended soil changed to neutral while that of other bio-stimulated soil changed from slightly alkaline to very slightly alkaline. At the end of the study (8WAA), all soil examined were relatively very slightly alkaline. The $\mathrm{CO}_{2}$ evolved were significantly different $(P<0.05)$ across the weeks with each bio-stimulant (Table 6). At 2 WAA PDp amended soil had the highest microbial respiration as revealed in the amount of $\mathrm{CO}_{2}$ evolved while the SMf amended soil had the lowest. At 4 WAA, the trend changed, BCMf amended soil was highest in the amount of $\mathrm{CO}_{2}$ evolved while the control had the least amount. All the other bio-stimulated soils were not significantly different from each other.

Table 6: Effect of bio-stimulants on $\mathrm{CO}_{2}$ evolved in oil polluted soil

\begin{tabular}{|c|c|c|c|c|}
\hline \multirow[b]{2}{*}{ Teathents } & \multicolumn{4}{|c|}{ 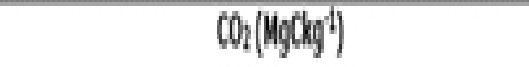 } \\
\hline & $2 \mathrm{WM}$ & $4 W M$ & 6WM & $\$$ WM \\
\hline Polvowomes' & $11 \%$ & 349 & 4,69 & $14.2 \gamma^{2}$ \\
\hline buto dowping & $3 \%$ & $36 x^{2}$ & 19,66 & 22.54 \\
\hline Swampripl & 17.14 & 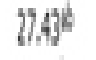 & $18 \%$ & $146 \%$ \\
\hline Symentif & $12 \%$ & 194 & 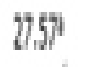 & 65 \\
\hline Bilon mive (b) & $152{ }^{*}$ & $6 \%$ & $x_{4} y^{b}$ & 14,8 \\
\hline Bet cats mote (f) & 17.4 & Min & $x 81$ & 20.44 \\
\hline Cothtsit & 279 & $10.7 \%$ & W.1.16 & 8.0h \\
\hline
\end{tabular}

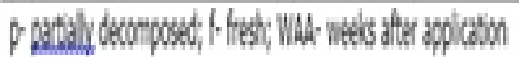

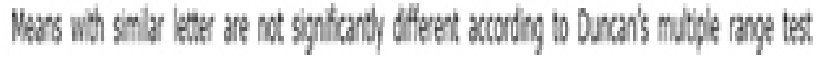

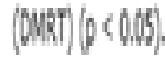

At 6 WAA, SMf, BCMf and PDp significantly enhanced microbial respiration with similar amount of $\mathrm{CO}_{2}$ evolved, while control still had the least. Finally, at 8 WAA similar trend was observed as with that observed at 6 WAA where BCMf and SMf enhanced microbial respiration and the least $\mathrm{CO}_{2}$ evolved was obtained in unremediated (control) soil. On the overall, it was observed that initially unremediated soil enhanced microbial respiration as reflected in the amount of $\mathrm{CO}_{2}$ evolved. However, microbial 
respiration consistently reduced with time in unremediated soils while BCMf consistently enhanced microbial respiration with time. This finding further validates earlier result discussed, showing BCMf to be the most effective in terms of soil remediation.

\section{Discussion}

The result of this experiment showed that all the bio-stimulating treatments applied had the potential to reduce THC and enhance microbial activity as revealed in the level of soil microbial respiration. This could be attributed to the fact that these bio stimulants have been reported to have loads of microbes of diverse population with broad enzymatic capacity needed to eliminate complex mixtures of hydrocarbons in the soil (Adebusoye et. al., 2007). All the biostimulants effectively remediated the contaminated soil; however, they varied in their remediating potentials as reflected in the THC, $\mathrm{CO}_{2}$ evolved and soil pH buffering capacity at different time, but on the overall, fresh cattle manure was the most effective at the end of the experiment.

The levels of THC of the contaminated soil decreased over time and varied significantly based on each treatment. The highest THC percentage degradation $(66 \%)$ and biodegradation efficiency was obtained at 8 WAA with fresh beef cattle manure. This result could be attributed to the fact that cattle manure is a by-product of rumen compartmentwhich is known to be a reservoir of diverse species of microorganisms (Janssen and Kirs, 2008) hence, it may be probably higher in microbial biomass than other biostimulants. Microbial respiration which is a measure of microbial activity increased in all the contaminated soil amended with biostimulants but a steady decrease was observed in the control throughout the incubation period. At 8 weeks of incubation, microbial respiration was highest in the fresh beef cattle amended soil and least in the control (unamended) soil. This finding further validates the claim that cattle manure is richer in microbial biomass than other biostimulants used in this study and this also corroborates the fact that petroleum hydrocarbons were degraded better by the fresh beef cattle manure during bioremediation process.

The observed increase in soil $\mathrm{pH}$ from neutral to slightly alkaline range in response to addition of biostimulant is in agreement with the work of Onuoha et. al. (2014), who obtained a gradual change in $\mathrm{pH}$ with time from the acidic to slightly alkaline range in response to the application of the organic waste. This amelioration of the soil $\mathrm{pH}$ might have contributed immensely towards the enhancement of bioremediation processes which has been found to depend majorly on Microbial activity, and micro organisms require optimal pH to sustain biodegradation (Jain et. al., 2011).

\section{Conclusion}

This study demonstrated that fresh beef cattle manure is a good organic substrate containing diverse species of microorganisms which have great potentials for enhanced bioremediation of crude oil contaminated soil. Fresh beef cattle manure applied at $20 \mathrm{t} \mathrm{ha}^{-1}$ would enhance biodegradation of hydrocarbon by increasing microbial activities through the slow release of nutrients and its contribution to microbial community in the contaminated soil. Fresh beef cattle manure had the highest percentage degradation, biodegradation efficiency and microbial activities. It is therefore concluded that fresh beef cattle manure could be a processefficient bioremediation option for hydrocarbon contaminated soil.

\section{References}

Adebusoye, S. A., Ilori, M. O., Amund, O. O., Teniola, O. D. and Olatope, S. O. (2007). Microbial degradation of petroleum hydrocarbons in a polluted tropical stream, World J. Microbiol. Biotechnol. 23 (8): 1149 1159.

Adesodun, J. K. and Mbagwu, J. S. C. (2008). Biodegradation of waste lubricating petroleum oil in a tropical alfisol as mediated by animal droppings. Bioresour Technol. 99: 5659-5665.

Akinde, S. B. and Obire, O. (2008). Aerobic heterotrophic bacteria and petroleum utilizingbacteria from cow dung and poultry manure. WorldJ.Microbiol.Biotechnol.24,1999 - 2002. 
Bhattracharya, P., Samal, A. C., Majunder, J. and Santra, S. C. (2010). Arsenic contamination in rice, wheat, pulses and vegetables: A study in an arsenic affected area of west Bengal, India. Water, Air, Soil Pollut. 213:3 - 13.

Farag, S. and Soliman, N. A. (2011). Biodegradation of Crude Petroleum Oil and Environmental Pollutants by Candida tropicalis Strain. Braz. Arch. Biol. Technol. 54 (4): 821830.

FME (2006). Federal Ministry of Environment Abuja, Nigerian Conservation Foundation Lagos, WWF UK and CEESP-IUCN Commission on Environmental, Economic, and Social Policy, May 31,(2006). Niger Delta Resource Damage Assessment and Restoration Project.

Jain K, and Bajpai, V. (2012). Biotechnology of bioremediation - a review. Int. J. Environ. Sci. 3(1): 535 - 549.

Janssen, P. H. and Kirs, M. (2008). Structure of the archaeal community of the rumen. Appl.

Environ. Microbiol. 74: 3619 - 3625

Mansour M. A., Bottefroy, D., Linder A. (1999). Inhibition of Bacillus lincheniformis spore growth in milk by nisin, monolaurin, and $\mathrm{pH}$ combinations. J. Appl. Microbiol. 86: 311 - 324.

Millioli, V. S., Servulo, E. L. C, Sobral, L. G. S., De Clor, W. and Iho, D. E. (2009). Bioremedation of crude of bearing soil: Evaluating the effect of Rhamnnolipid addition to soil toxicity and to crude oil biodegration efficiency. Global Nest J. 11(2): 181 - 188.

Mishra S., Sarma, P. M. and Lal, B. (2004). Crude oil degradation efficiency of a recombinant Acinetobacter baumannii strain and its survival in crude oil-contaminated soil microcosm. FEMS Microbiol. Lett. 235(2): 323 - 331.

Nievas, M. L., Commendatorea, M. G., Esteves, J. L., Bucal'a, V. (2008). Biodegradation pattern of hydrocarbons from a fuel oil-type complex residue by an emulsifier- producing microbial consortium. J. Hazard. Mater. 96 - 104.

Obayori, O. S., Ilori, M. O., Adebusoye, S. A., Oyetibo G. O. and Amund, O. O. (2008). Pyrenedegradation potentials of Pseudomonas species isolated from polluted tropical soils. World J. Microbiol. Biotechnol. 24: 2639 - 2646.

Onuoha, S. C., Olugbue, V. U., Uraku, J. A and Uchendu, D. O (2011). Biodegradation potentials of hydrocarbon degraders from wastelubricating oil spilled soils in Ebonyi State, Nigeria. Int J Agric Biol. 13: 586 - 590.

Onuoha, S. C., Chukwura E. I. and Fatokun, K. (2014). Stimulated Biodegradation of Spent Lubricating Motor Oil in Soil Amended with Animal Droppings. Amer Jour of Bio Science, 2 (1): $19-27$.

Roane, T. M. and Kellog, S. T. (1996). Characterization of bacterial communities in heavy metal contaminated soil. Canadian J. Microbiol. 42: 593 - 603.

Sathishkumar, M., Binupriya, A. R., Baik, S. H. and Yun, S. E. (2008). Biodegradation of crude oil by individual bacterial strains and a mixed bacterial consortium isolated from hydrocarbon contaminated areas. Clean. 36 (1): 92 - 96

Stanley, H. O., Offorbuike, O. M., Stanley, C. N. (2017). Bioremediation of Crude Oil Contaminated Soil Using Pleurotuspulmonarius, a White-rot Fungus. J Environ Sci Toxicol Food Technol. 11 (4):122 - 128.

Ukoli, M._K. (2005). Environmental Factors in the Management of the Oil and Gas Industry in Nigeria.www.cenbank.org

Vankateswaran, K. T. Hoaki, M., Kato and T. Murayama, (1995). Microbial degradation of resins fractionated for Arabian light crude oil. Canadian J. Microbiol. 41: 418 - 424

Walkley, A. and Black, C. A. (1934). An examination of the digestive method for determining soil organic matter and a proposed modification of the chromic acid titration method. Soil Sci. 37: 29 - 38.

Zhang, Z. G., Hou, Z., Yang, C., Mac, W. Z., Sun, B., He, X., Tang, H., Xu, P. (2010). Characterization and biotechnological potential of petroleum degrading bacteria isolated from oil-contaminated soils. Bioresour Technol. 10: 8452 - 8462. 